\title{
Development of Effective Academic Affairs Administration System in Thai Primary Schools
}

\author{
Niratchakorn Thongnoi ${ }^{1}$, Boonchom Srisa-ard ${ }^{2} \&$ Anan Sri-ampai ${ }^{3}$ \\ ${ }^{1}$ Doctor of Education Degree Candidate (Educational Administration and Development), Faculty of Education, \\ Mahasarakham University, Thailand \\ ${ }^{2}$ Associate Professor, Faculty of Education, Mahasarakham University, Thailand \\ ${ }^{3}$ Ph.D. Faculty of Education, Mahasarakham University, Thailand \\ Correspondence: Niratchakorn Thongnoi, Doctor of Education Degree Candidate (Educational Administration \\ and Development), Faculty of Education, Mahasarakham University, Thailand. Tel: 66-812-602-929. E-mail: \\ niratchakorn@gmail.com
}

Received: August 15, $2013 \quad$ Accepted: September 22, $2013 \quad$ Online Published: September 29, 2013
doi:10.5539/ies.v6n10p139
URL: http://dx.doi.org/10.5539/ies.v6n10p139

\begin{abstract}
This research aimed to: 1) study current situations and problems of academic affairs administration system in Primary Schools. 2) develop an effective academic affairs administration system, and 3) evaluate the implementation of the developed system in the primary school, Thailand. Research and Development (R\&D) was employed which consisted of the analysis of the current states and problems of the academic affairs administration system in primary schools, designing and verification of the developed system by experts, and implementation and evaluation of the developed system. The survey was used to analyze the current states and problems by 750 respondents as the samples, including school administrators and heads of academic affairs. The developed system was verified by nine experts. The developed system implementation was evaluated and informed by eleven school administrators and teachers. The research instruments included: questionnaires, evaluation form, semi-structured interview form, and school record form. The results showed that current situations of Thai primary schools academic affairs administration system, the practices were at high level, and the problems were at moderate level. The developed academic affairs administration system consisted four main aspects and among those there were nineteen components; the input aspect was comprised of six components, the process aspect comprised of eight components, the output aspect comprised of three components and the feedback comprised of two components. The usage of developed academic affairs administration system could significantly improve the students' quality in higher level. In addition, administrators and teachers had satisfaction in system use.
\end{abstract}

Keywords: academic affairs administration system, effective, Thai primary schools

\section{Introduction}

\subsection{Challenges}

The main problems in Thai education system lie in the fact that there is inefficient administration and management (Office for National Education Standards and Quality Assessment, 2010). The Office of Secretary the Education Council (2010) revealed that one sub-factor of fundamental structure showed that Thailand competitive capacity in education was ranked as 47 of 57 and that ranked down 4 levels compared to the year 2009. Moreover, the Program for International Student Assessment (PISA) also showed that the effectiveness of 15 year-old students in mathematics and sciences was gained under $50 \%$ of total grades and English use is ranked as 51 compared to 57 countries in the competition list (Office of the Education Council, 2010). In the part of educational management, International Institute for Management Development considered the budget that the government allocated to the education sector and it showed that Thailand ranked as 52 compared to other countries in the world. Based on these competitive ranking components, Thai education capacity is comprised of the education opportunities, quality, and the effectiveness which were unsatisfactory and still at low quality compared to the previous years. 
The performance of Thai children has continually gone down. This can be gauged from various types of Ordinary National Educational Test (O-NET). It was found that the scores of Thai students who responded for the test in 2010 were lower than $50 \%$. Grade 9 students passed in just one subject: health education. They failed in all other subjects. The results of O-NET in 2011 showed that Grade 6 students secured scores higher than 50\% in mathematics, social studies, culture and physical education, however, their scores were lower than $50 \%$ in English, and art (National Institute of Educational Testing Service, 2012). In terms of primary school, the evaluation conducted by the external education quality during 2006-2010 found that the average value in 14 standards was satisfied. Among the total of 12,268 Thai primary schools, $79.10 \%$ accredited and $20.93 \%$ were not accredited.

The poor performance of Thai primary schools in administration and management was indicated in the second round of external quality assessment. This poor performance was caused by the poor quality standard of student development competencies such as: critical thinking and practical capacity, problem solving abilities, curriculum based outcomes, learning commitments, and lifelong learning. In terms of school administration and management, it was comprised of improper curriculum development, poor student-center teaching and learning style, low quality in standard improvement, and ineffective teaching and learning capacity (Office of National Education Standards and Quality Assessment, 2010).

The above problems were related to the problem solving to be implemented as holistic one without separation into parts, especially the academic affairs administration system, including the effective academic work of schools which would help to elevate the Educational Quality of schools with adequate as well as appropriate support of resources by the government, including the Public Educational Policy, precisely and continuously, sufficient budget, the rules and regulations facilitating Quality Development, Teacher Development to obtain professional competency, and the administrators' academic leadership.

\subsection{Academic School Leaders}

Since the1999 Thai education reform, schools have more opportunity to make decisions and responses to the decentralization of power to schools more responsibly. It is very critical that administrators are required to be aware of and equipped with administrative skills. This refers to the five principles of the role, position, and attitude of the school leaders. There are curriculum development, instructional development, student administration, community services, and resources and facility management (Ubben and others, 2001). These five principles of leadership can lead the school to happiness and benefit the teachers, students, and schools themselves. The instructional leadership was developed from the transformational leadership. This leadership style is specified for school principals based on the knowledge of educational theories, instructional, and curriculum development and management and it is also a driving force in educational development. According to this combination, this leadership style was called "academic leadership", comprised of capacity for communication with teachers, students, and parents (McEwans, 1998).

\subsection{School Leader as Transformer}

The development of educational quality in schools is a significant responsibility for school leaders. The school leaders have to be people who can plan for educational outcomes in advance for the school, be aware of specific knowledge and experiences in educational administration, and be equipped with the knowledge of politics, society and relationship that can motivate school leaders to be active in applying their leadership. The playing role as the model of teaching and learning activities, school vision formulation, and school quality assurance are required for school leaders. Moreover, motivation for internal and external stakeholders such as teachers and communities around with a new vision in working and surviving is needed (Razik, 2001). The school leaders' roles and responsibilities consisted of coaching and monitoring school teachers, ability to design the processes and models for curriculum development, capacity in school resources management, flexibility with the new context of teaching and learning, understanding of students' learning behaviors, ability to design the instructional model, and the application of new techniques in teaching and learning processes.

According to the reviews of Drucker (1996), it is mentioned that effective leaders can be developed and it is not relevant to personal performances, styles, capacities, or the interests of those leaders. Effective leaders demonstrated 4 points of view: first, the effective leader must have followers, second the effective leader has to have outcomes-based thinking and implementation orientation, third the effective leader has to be a role model and fourth, the effective leader has to be responsive to vision, mission, objectives of organization and responsibilities in utilizing curriculum and managing the learner-centered processes (Kaewkeeyun, 2002). Student commitment for learning, quality of teaching, and school administration affects education and is in direct relationship (Dimmock and Walker, 2005). The school principal leadership must be equipped with academic 
spirit in order to determine student outcomes and also play the role of coordinator to assist students and teachers in teaching and learning activities (Leithwood, 2006).

\subsection{Effective System as the Transformational Tool}

School development is the critical role of school principals (MacNeill and others, 2003). They also play integral roles as school leaders in bringing about achievement and success for students through supporting, conserving and preserving the school environment through strategic plans to reinforce the effectiveness of teaching and learning for sustainable development of teaching profession (Hoy \& Hoy, 2003). It is pivotal to take into account the efficiency of the school leaders who are capable of working in teams and initiating solution-based mechanism in practically strengthening the sustainability of the school's development. Therefore, it is indispensable to have educational leaders pertaining to the politically ethical virtues, understanding the societal, economic, and human-kind needs, realizing the inter-related needs of the government and society, understanding to be accountable and conceptualizing professional possibilities. School is one of the key components of the society inter-dependent in management structures and other inter-related infrastructures in both formal and informal manners engaged in decision making in educational management (Cunningham and Cordeiro, 2003).

Wad Banpang School, under the Office of Basic Education Commission, the Office of Roi-Et Primary Educational Service Area 1, included a total of 158 students, 1 administrator, and 10 teachers. It is a school with quality of academic management work lower than standard. According to O-NET, and ranking in achievement learning, it was ranked in $228^{\text {th }}$ out of 235 schools, and willing to participate in the research. Therefore, the researcher selected Wad Banpang School for academic administration system (Office of Roi-Et Primary Educational Service Area 1, 2010).

\section{Objectives of Study}

This research aimed: 1) to investigate the current situations and problems of academic affairs administration system in Thai primary schools, 2) to develop the effective academic affairs administration system, and 3) to evaluate the implementation of the developed system in the primary school.

\section{Method and Instruments}

Research and Development (R\&D) was employed for this study by using mixed methods research techniques by collecting data through quantitative as well as qualitative technique. This study is designed to develop the academic affairs administration system in Thai primary schools and is divided into three stages:

1) the survey of the current situations and problems of academic affairs administration systems from the samples of 750 primary school administrators and heads of school academic affairs who were respondents by using the questionnaire as 5 Level Rating Scale. Data were analyzed by calculating the Mean, and Standard Deviation, 2) the design of effective academic affairs administration system in primary school, including: 2.1 the study of academic administration systems in 2 schools with best practices by interviewing the responsible school administrators and academic teachers via the semi-structured Interview, and 2.2 the outlining of effective academic affairs administration system in primary school by using data from Stage 1, and the study of best practices, and investigation as well as evaluation of the system by 9 experts. The research instruments consisted of the System Evaluation Form as 5 level rating scale. Data were analyzed by calculating the Mean, and Standard Deviation, and 3) the usage of developed system in Wad Banpang primary school. Data were collected by collecting the findings in usage of documentary analysis, O-NET examination report, and analyzing data by comparing the test performance with O-NET evaluative criterion, and using the questionnaire of the administrators and teachers' satisfaction on system use, 5 level rating scale. The key informants were 1 administrator and 10 teachers. Data were analyzed by calculating the Mean, and Standard Deviation.

\section{Results}

The following results of the study, respective of research objectives were as follows.

\subsection{Current Situations of Thai Primary Schools Academic Affairs Administration System}

The practices were at high level. considering each aspect of academic affairs, the practices were also at high level as well. problems as a whole and individual aspects were at moderate level.

\subsection{The Findings of Effective Academic Affairs Administration System in Primary School were as Follows}

\subsubsection{The Input Factor}

The Input Factor consisted of: the administrators' academic leadership, teachers' competency, students' characteristics, learning process management, learning environmental management, and obtained resources. 


\subsubsection{The Process Factor consisted of 8 Sub-Factors}

These eight Sub-factors were called "Sub-System". Each Sub-System was a work unit of academic affairs administration system of primary school including: the school curriculum development, the Learning Process Development and Management, the measurement and evaluation and transfer of learning performance, development of media and technology for education, the development and support for learning sources, research for Educational Quality Development, Educational Supervision, and Internal Quality Assurance and Educational Standard, the mechanism for working movement of total of 8 sub-units consisted of the planning, action, and evaluation.

\subsubsection{The Output Factor}

The Output Factor consisted of the students' quality and characteristics, the teachers' comprehension of curriculum and competency in using technology for instructional development, and teachers and administrators' satisfaction of the academic administration system.

\subsubsection{The Feedback Factor}

The Feedback Factor consisted of the findings of students' learning performance, and characteristic development.

The obtained system could indicate the system structure as shown in Figure 1:

\begin{tabular}{|c|c|c|}
\hline $\begin{array}{l}\text { Inputs } \\
\text { 1. Administrators' academic } \\
\text { leadership } \\
\text { - Vision, missions, and } \\
\text { objectives of learning } \\
\text { - Management of curriculum } \\
\text { and teaching } \\
\text { - Development of students } \\
\text { - Development of teachers } \\
\text { 2. Teachers' competency } \\
\text { - Knowledge and } \\
\text { experiences in profession } \\
\text { - Skills and abilities } \\
\text { - Motivation } \\
\text { - Personality } \\
\text { 3. Students' characteristics } \\
\text { - Skills in pursuing } \\
\text { knowledge } \\
\text { - Necessary knowledge and } \\
\text { ability according to the core } \\
\text { curriculum of } 2008 \\
\text { 4. Leaming process } \\
\text { management } \\
\text { - Learner-centered } \\
\text { - Activities to promote the } \\
\text { quality of learners } \\
\text { - Thinking process focused } \\
\text { - Atmosphere favorable to } \\
\text { leaming } \\
\text { - Participation of those } \\
\text { - budget } \\
\text { involved - Buildings } \\
\text { 5. Leaming environment } \\
\text { management } \\
\text { - Material, equipment, } \\
\text { media and technology } \\
\text { Obtained Resources } \\
\text { - material and equipment } \\
\text { - }\end{array}$ & $\begin{array}{l}\text { - } \\
\text { - } \\
\text { Dehool Curriculum } \\
\text { Leaming Process } \\
\text { Administration and } \\
\text { Development } \\
\text { Learning Assessment and } \\
\text { Evaluation } \\
\text { ICT Development for } \\
\text { Learning and Teaching } \\
\text { Process } \\
\text { Development and } \\
\text { promotion of learning } \\
\text { resources } \\
\text { Research for developing } \\
\text { educational quality } \\
\text { Educational supervision } \\
\text { Internal quality assurance } \\
\text { and educational standard }\end{array}$ & $\begin{array}{l}\text { Outputs } \\
\text { 1. Students: } \\
\text { - Gaining higher learning } \\
\text { achievement level according } \\
\text { to the standard of the Office } \\
\text { of Basic Education } \\
\text { Commission } \\
\text { - Consisted of desirable } \\
\text { characteristics as per the } \\
\text { standard of a core curriculum } \\
\text { 2009 in terms of patriotism, } \\
\text { honesty, discipline, eagerness } \\
\text { to learn, sufficient life, hard } \\
\text { work, Thainess, public } \\
\text { oriented mind } \\
\text { 2. Teachers: } \\
\text { - Having an understanding of } \\
\text { the core curriculum of } 2008 \\
\text { - Having an ability to use } \\
\text { technology for teaching and } \\
\text { developing proper learning } \\
\text { process } \\
\text { - Being satisfied with the } \\
\text { effective academic affairs } \\
\text { administration system in } \\
\text { primary schools } \\
\text { 3. Administrator: they are } \\
\text { satisfied with the effective } \\
\text { academic affairs administration } \\
\text { system in primary schools }\end{array}$ \\
\hline
\end{tabular}

Figure 1. Effective Academic Affairs Administration System 


\subsection{The Implementation of the Developed Effective Academic Affairs Administration System in the Primary School (Wad Banpang School in Roi-Et Province, Thailand).}

The Results Indicated That:

For students: the students gained higher learning achievement which was seen through the findings of O-NET in 2012. The average scores of the test as acquired by the students were higher and their average scores were higher than those of the students at the educational service area level. The performance level had risen from the $30^{\text {th }}$ ranking from the bottom to the $2^{\text {nd }}$ ranking. The average scores were ranked $64^{\text {th }}$ up from the $228^{\text {th }}$ rankings. The students had the desirable characteristics as per the criteria of the core course of 2008 representing $100 \%$.

For teachers: the teachers were aware of and had knowledge of the development of an effective administrative system; they upgraded themselves in using the curriculum, media, an assessment and evaluation, arrangement and development of a variety of the learning sources.

For administrators: the administrators and the teachers had a high satisfaction with the effective academic affair system developed by the researcher. Given individual aspects, it was found that the satisfaction was at a high level in the factors of input, process, and feedback. The satisfaction was the highest in the output factor.

The effective academic administration system: The implementation of the developed system pursuant to ideas of administration, including planning, action, and evaluation.

\subsubsection{Planning}

Awareness and Recognition by the school administrator: The researcher provided details of the research and explained the importance, the roles and duties of the administrator in determining the policy of budget and expected benefits for the students and the school. The school administrator and the teachers were willing to cooperate and exchange opinions regarding the issues of Wad Banpang School.

Creation of an awareness and a recognition of the teachers at Wad Banpang School: according to the conference, attended by 1 administrator and 10 teachers from Wad Banpang School. It was found that the school academic administration was moderate in terms of input, process, output and feedback. Data were not systematically stored and there was no formal documentation. The meeting held that priority should be given to the development of students learning achievement, learning development, measurement and evaluation and transfer of the results, development of educational media and technology, enhancement of learning sources, research for educational development, educational supervision, internal quality assurance and standards.

Roles and duties of those concerned with the implementation: It was necessary to determine the roles and duties of all people responsible for developing the effective administration system. The committee was appointed to follow and evaluate the academic administration. The committee consisted of the administrator, the head teacher for academic affairs, and teachers to monitor and evaluate the results.

The meeting was held at the school under study: The researcher and administrator explained the objectives and asked for cooperation from all students in developing the process. Then the school administrators, academic affairs head evaluated. The questionnaires and the interviews were administered with the subjects: administrators, academic affair head, teachers as well as documents, evidences included. The purpose was to know the system in operation prior to the development of the system created by the researcher. It was found that prior to the development of the effective academic administration system, the overall implementation was moderate. Considering the individual aspects, it was found that the school used the core curriculum for the basic education of 2008. The local curriculum was the one which has been in use since 2009. In addition, not all indicators were evaluated. In terms of the learning process, the teachers from each learning group were tasked for managing the learning process; however, they lacked technological skills. Besides, the learning sources were inadequate. As regards the measurement, evaluation and transfer of the learning results, the forms of measurement and evaluation used by the school were not diverse. The materials for teaching and learning were inadequate as some teachers still lacked skills in using technology. There was a variety of learning sources in the school, but there was no continuous development thanks to budget constraints and lack of support.

The teachers failed to conduct researches as required. If they did, their research was not kept systematically. The educational supervision was conducted in a friendly manner once in a month. It was mainly done during the lunch break; therefore it was not systematic. The internal quality assurance and the educational standard were undertaken according to Item 14 of the Office of the Basic Educational Commission of 2011. 
Table 1. The assignments of roles and duties

\begin{tabular}{|c|c|}
\hline $\begin{array}{l}\text { The Person in } \\
\text { Charge }\end{array}$ & Roles and Duties \\
\hline \multirow[t]{7}{*}{$\begin{array}{l}\text { School } \\
\text { Administrators }\end{array}$} & $\begin{array}{l}\text { 1. Work with teachers and others in determining the policy, vision, mission and } \\
\text { objectives }\end{array}$ \\
\hline & 2. Provide support in budget, materials and equipments \\
\hline & $\begin{array}{l}\text { 3. Hold a meeting to inform the role and duty of those concerned to operate } \\
\text { according to the academic administration system. }\end{array}$ \\
\hline & 4. Appoint a committee to supervise, follow-up, monitor and evaluate. \\
\hline & $\begin{array}{l}\text { 5. Take part in planning and implementing the supervision, monitoring, and } \\
\text { evaluating of the academic administration. }\end{array}$ \\
\hline & $\begin{array}{l}\text { 6. Make available information of the effective academic administration to the } \\
\text { committee }\end{array}$ \\
\hline & 7. Participate in evaluating the system development. \\
\hline \multirow{6}{*}{$\begin{array}{l}\text { Head Teacher of } \\
\text { Academic Affairs }\end{array}$} & 1. Study the handbook on the system \\
\hline & 2. Attend the workshop and study the works related to academic administration. \\
\hline & 3. Put into practice knowledge and experiences gained from training and field study. \\
\hline & 4. Provide the information of the implementation to the committee. \\
\hline & $\begin{array}{l}\text { 5. Be a committee of supervision, monitoring and evaluation of the academic } \\
\text { administration. }\end{array}$ \\
\hline & 6. Join in the evaluation of the system development. \\
\hline \multirow[t]{5}{*}{ Teachers } & 1. Study the handbook on the system \\
\hline & 2. Attend the workshop and study the works related to the academic administration. \\
\hline & $\begin{array}{l}\text { 3. Put into practice knowledge and experiences gained from the training and field } \\
\text { study. }\end{array}$ \\
\hline & 4. Provide information of the academic administration to the committee. \\
\hline & 5. Join in the evaluation of the system development. \\
\hline $\begin{array}{l}\text { Students' } \\
\text { Representatives }\end{array}$ & $\begin{array}{l}\text { Join in planning, monitoring, and evaluating the effective academic administration in } \\
\text { the primary schools. }\end{array}$ \\
\hline $\begin{array}{l}\text { Parents' } \\
\text { Representatives }\end{array}$ & $\begin{array}{l}\text { Provide the information in evaluation of students' ability in the activity projects } \\
\text { which enhance the effective academic administration }\end{array}$ \\
\hline \multirow[t]{4}{*}{ Researchers } & $\begin{array}{l}\text { 1. Explain and create an awareness in the roles and duties according to the effective } \\
\text { academic administration system in the primary schools. }\end{array}$ \\
\hline & 2. Be a joint academic person in workshop. \\
\hline & $\begin{array}{l}\text { 3. Be a committee of supervision, monitoring, and evaluating the effective academic } \\
\text { administration system in the primary schools. }\end{array}$ \\
\hline & $\begin{array}{l}\text { 4. Join in planning, monitoring, and evaluating the effective academic administration } \\
\text { in the primary schools. }\end{array}$ \\
\hline
\end{tabular}

\subsubsection{Action}

The researcher coordinated with the school committee in monitoring and evaluating in order to determine the strategy and guidelines in utilizing the system in question in the developments, for example, the field work, the workshop, the actual practice in the classroom. The outcomes of each activity were illustrated as follows.

Following the workshop: the researcher took the administrator and the teachers for the field work at the schools with excellent practice in academic administration to enable them to gain first-hand experience of the circumstances in these primary schools. The tools and instruments used in data collection were the opinion 
evaluation form, digital cameras, and the recorders. It was found that the teachers' opinion on the study of the academic administration was at a high useful level.

The conference, and the workshop: It was aimed to establish knowledge and understanding and make the school administrators, the head teachers of the academic affairs and the teachers totaling 11 to appreciate the academic affairs administration. The experts came from the Office of Roi-Et's Educational Service Area 1. Based on the workshop operation, it was found that the participants acquired knowledge, and were aware of the significance of the effective academic administration. Based on the results, it was found that the participants had a high level of satisfaction towards the effective academic administration.

Actual practice: the researcher had a meeting with the administrators and the teachers to discuss and exchange views and plan how to completely utilize the handbook for one full semester.

\subsubsection{Evaluation}

The school administrator and the teachers were aware of the significance of the implementation of the effective academic administration system. The evidence was acquired from the interviews before and after the use of the academic administration system and from the observation of the actual practice. It was found that the teachers improved in using the media, measurement and evaluation. Learning sources were diverse.

The school administrator and the teachers were satisfied with the academic administration system. It was based on the evaluation of the satisfaction in using the system and practicing in the media room. The teachers made progress in using the curriculum, and media, in measuring and evaluating. They made available a variety of learning sources. As regards the satisfaction of the school administrator and the teachers in the effective academic administration system following its introduction, it was found that the overall satisfaction was at "high" level. As for individual aspects, it was found that input, process, feedback and output had the satisfaction at a high level in all aspects.

Data were synthesized from the interviews of the administrator and the teachers concerning the development of the learners before and after the use of the academic administration system.

Development of the curriculum: Before using the system, the learning-teaching management was based on the core curriculum for the basic education of 2551 B.E. After the use of the system, knowledge of curriculum increased. The curriculum could be adapted according to the school context. The curriculum and the indicators became more precise. The curriculum was used to enhance the efficiency of the learning-teaching.

Development of learning process: before using the system, it is important to understand the learning process, for example, the learning plan, media, measurement and evaluation. Individual teachers used to manage the learning process according to their own methods. They implemented the learning process according to the students' context. There was no clear frame or content. There was no management or learning plan. After using the system, there was learning management relevant to the indicator. There was learning management. Learning and teaching were implemented according to the plan which was emphasized on the learners. Suitable techniques and methods were introduced.

Measurement, evaluation and learning transfer: before using the system measurement and evaluation were taken according to the learning units in the semester. The measurement was based on the test or the students' performance (assignments), which proved unsatisfactory. The measurement was unsatisfactory as the evaluation did not cover the content of the curriculum. After using the system, the measurement and evaluation were more systematic. The head teacher for academic affairs was tasked in helping other teachers. The measurement and evaluation were more inclusive. In the process of measurement and evaluation, a variety of instruments was used, considering the appropriateness for the learners and the learning units. The results of learning management were analyzed to be used to improve the effective way of learning.

Development of educational technology: before using the system the teachers rarely used the teaching media. In addition, the materials used in teaching were limited and not up-to date. They were not interesting for the learners. The teaching materials were not systematically maintained. After using the system the schedule and registration were set for using the media room. A teacher was responsible for helping other teachers who were not endowed with technological knowledge. This resulted from reciprocal actions in the agency. The material or media which were used were more diverse and interesting for the learners. It was easy to maintain and use.

Development and enhancement of learning sources: 1). before using the system the learning sources were made available according to the school's potential. The sources were few and insufficient for the needs of both the teachers and the students. The available budget was limited. The available sources were not adequately utilized. They didn't serve the demand and were ineffective. 2). after using the system, more learning sources were 
developed and utilized. The classrooms were modified as learning sources. A space was kept as the reading corner for the classroom. Modern media and materials were used in learning and teaching. The schedule for using the learning sources was set systematically. Learning sources both inside and outside the school were developed. Interestingly, the learning sources were diverse and favorable for teaching and learning.

Research for the educational quality: 1). before using the system the teachers used traditional techniques in teaching and learning; no research was conducted. As a result, they lacked knowledge and understanding of research as they viewed that research was difficult. 2). after using the system the teachers became more interested in research. And when they did research, they did so with more understanding. Their research was more systematic and diverse and in responsible for real situations.

Educational supervision: 1). before using the system the supervisor lacked knowledge of the role and duty he or she was supposed to carry out. The supervision was not systematic and not continuous. Thanks to the absence of a diversity of supervision, the supervision did not respond to the actual conditions. 2). after using the system the plan was set for activities, the supervision chart and the classroom supervision record. The supervision became more systematic and could be used to develop personnel commitment. The supervisor gave more priority to the supervision process.

Internal quality assurance and educational standard: 1) before using the system the teachers lacked an understanding of the evaluation methods in preparation for the internal quality assurance and implementation of educational standard. Documentation was not systematic. The project was implemented occasionally. 2) after using the system, many things were more categorized. Documents and relevant papers were systematically arranged. The steps were continuous. The internal quality assurance grew more effective. The system put in place led to success and achieved the set educational criteria.

\section{Discussions}

Regarding the current situation of academic administration system in primary school, practices were at high level. Although the practices were at high level, there were problems in academic work practice under the current system which were reflected by the students' low level of learning achievement as well as the lack of some desirable characteristics. It indicated that practices under the recent system, were ineffective. Considering the academic administration at the primary schools prior to the development, it was found that overall the difficulties were moderate. This might be due to the fact that the administrators and the teachers understood the academic administration, but there were problematic issues; the implementation of the academic affair in the schools lacked a clear system; the environment was unfavorable; the budget was insufficient. The findings were in accordance with the work conducted by Templer (1995) who found that the school administrators were the first factor which contributed to an accomplishment in an effective academic affairs administration system. If the administrators were aware of the importance of the important role played by the learners, it could affect policy significantly. The assessment and evaluation required continual development. Both the administrators and the teachers had to secure and develop learning sources, create motivation and give an opportunity to those concerned to cooperate in dealing with problems.

Smith (1991) conducted research on an effective administration system in Jorgia. It was found that major components contributing to the efficiency of the school were continual measurement and evaluation, academically favorable atmosphere and strong leadership, high expectation and cooperation. The finding was in compliance with the work of Songprasert (2007) who conducted research on the model of the academic administration in primary educational establishments. He found that the key components were leadership in instruction, the academic team, the academic mission and networks in the educational establishments.

Considering the factors of the input, the process, and the output, it was found that the students had higher desirable characteristics according to the standard of the Office of the Basic Educational Commission and the teachers and the administrators were satisfied with the effective academic affair administration system used in the primary schools. According to O-NET in 2012, the average score of students in Wad Banpang School was higher. It was higher than the Educational Service Area, and moved from the rank of 228 into $64^{\text {th }}$. In addition, $100 \%$ of students had desirable characteristics based on criteria of Core Curriculum of Basic Educational Management 2008. The teachers had awareness, knowledge, and comprehension in developing the effective academic administration system. They also made progress in curriculum and media use, measurement and evaluation, and provided as well as developed various internal learning sources: Educational Media and Instruction Room, Computer Room. For the administration and teachers' satisfaction on the usage of effective academic administration system, it was found that satisfaction was at "High" level. The findings were identical to the work performed by Rupan (2003) who did research on developing the evaluation system. He found that 1) 
the model of the evaluation system of the Commission of the Basic Education consisted of four aspects: input, process, output, and feedback. 2) The input comprised objectives, evaluation, indicators, criteria, instruments, evaluation papers, raters. 3) The process had planning, and developed evaluation instruments, data collection and analysis. 4) The output included the record of the evaluation summary, and the overall performance of the Commission of the Basic Education. 5) The feedback included that of the Commission of the Basic Educational Establishments and the Office of the Educational Service Area. 6) Based on the introduction of the performance evaluation system of the Basic Educational Commission, it was found that all components of the system were suitable at a satisfactory level. The evaluation result was up to standard. As regards utilization, suitability, and correctness, these were at "High" level. The result was consistent with that of Frase and Sorenson (1992) who researched the factors affecting the motivation and satisfaction of teachers in the schools with a participatory administration. It was found that motivation was connected with the teachers' satisfaction, including feedback from colleagues, and educational supervisors, autonomy, and growth need. In addition, students' achievement was higher, which was similar to the work conducted by Reeves (2010) who studied the relation of the academic setting and the atmosphere of individual bodies which were associated with the efficiency of schools.

It was found that the effective academic affairs administration system which was developed was suitable. The students had the desirable characteristics according to the criteria of the core course of the basic education 2008, accounting for $100 \%$. They had a higher learning achievement. The results of O-NET in 2011 of the students from Wad Banpang was ranked by the Primary Educational Service Area Office. It was found that Wad Banpang School students were ranked $228^{\text {th }}$ by the Educational Service Area 1 of Roi- Et province. Also based on the scores they had secured, the students from Wad Banpang were ranked $30^{\text {th }}$ in the district of Janghan. With the effective academic system introduced at the school in question for six months, it turned out that in the O-NET exam, the average scores of the students of Wad Banpang improved in seven subjects. Based on the average scores, the students were ranked in the second place. The average scores of O-NET moved up to the $64^{\text {th }}$ place from the $228^{\text {th }}$ ranking. The teachers gained better knowledge of the effective academic administration system. They had an improved development of usage in curriculum, media, measurement and evaluation; they could secure and improve the internal learning sources. Given the satisfaction of the administrators and the teachers towards the effective academic administration, it was found that the overall satisfaction was at high level. Considering each aspect, it was found that the input, process, feedback, and satisfaction were at higher level, thanks to the increased scores of the students under study.

The problems found in utilizing the system were listed as follows. regarding the input, the effective academic affairs administration system, the administrators' academic leadership, the teachers' faculty, the students' characteristics, the learning process, the learning atmosphere, and the resource availability. It was found that the administrators and the teachers lacked a profound understanding of the system and changes in the development of the effective academic affairs administration system. In addition, the teachers remained conservative, not being willing to face new changes. There were some teachers who opined that it unnecessarily wasted time as they had other work to do. They were of an opinion that they had better try to finish their teaching part within a given time. Furthermore, they lacked moral support from their superiors. Seeing the low average scores of their students, they were not confident that there was much they could do as the system was not effective and the information was not up - dated. Additionally, teachers were assigned not according to their ability and aptitude. The teachers had to teach the subjects that were not their major subjects as there were no teachers qualified for a particular subject. Thanks to this, they were gravely worried and not confident in themselves. Progress could not be fully realized in light of the development of the academic affairs administration system, school curriculum development, learning process administration and development, learning assessment and evaluation, ICT development for learning and teaching process, development and promotion of learning sources, research for developing educational quality, educational supervision and internal quality assurance and educational standard assurance. The reasons for not being able to fully realize these aspects were time constraints, insufficient personnel and excessive work loads. As a result, those concerned were not confident whether the system which was implemented would be worth trying. Concerning the output, the students had a higher learning achievement as per the standard criteria of the Basic Educational Commission Office, and possessed desirable characteristics as per the standard of the core course of 2008. The results of O-NET in 2012 showed the average scores of Wad Banpang students were higher than $50 \%$. The administrators and the teachers were satisfied with the effective academic affairs administration system of the primary schools. Given the feedback, there were reports of the development of the academic administration system. In terms of the input, the process, the feedback, the output in align with the recommendations and improvements, it was found that there were reports of the outcome of the system used to improve individual aspects and make the teachers more confident. In the beginning, the teachers 
were not confident whether they were able to upgrade the students' performance. The findings indicated that it was necessary for all to cooperate so that teachers and the students would be motivated and encouraged.

\section{Conclusions}

The results of this study indicated the benefits of the implementation of the developed academic affairs administration system in Wad Banpang School in Roi-Et Province, Thailand. The students gained higher learning achievement as seen from the results of O-NET in 2012. The average scores of the test as acquired by the students of Wad Banpang School were higher and their average scores were higher than those of the students from the educational zone level. The performance level had risen from the $30^{\text {th }}$ ranking from the bottom to the $2^{\text {nd }}$ ranking. The average scores were ranked $64^{\text {th }}$ up out of $228^{\text {th }}$ rankings. The students had desirable characteristics as per the criteria of the core course of 2008 representing $100 \%$. The teachers were aware of and had knowledge of the development of an effective administrative system; they upgraded themselves in using the curriculum, media, assessment and evaluation, arrangement and development of a variety of learning sources. The administrators and the teachers had a high satisfaction with the effective academic affairs system developed by the researcher. Given individual aspects, it was found that satisfaction was at a high level in the factors of input, process, and feedback. The satisfaction was the highest in the factor of outputs.

The effective academic affairs system leads to the efficient administrative system, which was in line with the concepts, theories and principles of the administration as stated in the objective of the basic education. In addition, it is appropriate with the context of the academic administration. The system is also useful for primary school administrators as it enables them to achieve the set goals as specified for the basic education organization. The conditions which contribute to success include strong commitment, sacrifice, and a new approach in thinking. Mutual cooperation proves extremely important in bringing about maximum benefits to the teaching and learning process.

\section{Recommendations}

\section{Applications}

For administrators: the administrators are required to clearly study the system in question. They should make the teachers, the students and related persons aware of significance in the effective academic system. They have to implement it at every step so that both individuals and schools will be developed together. However, activities should be adjusted commensurately with context. The system should be employed for a full year. The data of individual students should be available. Slow learners should be given a priority. A cooperative method is a vital step, leading to maximum benefits.

For the teachers: it is necessary for the teachers to understand the system and be cooperative in implementing the system. While putting the system into use, they should be more flexible. Without flexibility, other procedures may be affected. The teachers must realize the responsibility they have to fulfill. Using the system has to be continuous. They are to know how to integrate various aspects, for example, curriculum development, learning process development, evaluation, development of the media and technology for education.

For Students, Parents and the Commission of the Schools: They have to be aware of the development of learning and quality of students. They have to take time to take care of their children, cooperate and support activities and projects meant to improve the quality of learners.

\section{Further researches}

Research should be conducted on the model of the development of the learning process to raise the learning results.

A study should be conducted on motivation in the development of the quality of learners and those involved.

An in-depth study should be conducted in the effective academic affairs administration in the primary schools in each sub-system.

\section{Policies Set Up}

Educators should conduct research on the model of the development of the learning process to raise the achievement level.

Qualified and competent personnel should be recruited to be administrators. The appropriate recruitment system should be employed. 


\section{References}

Cunningham, W. G., \& P. A. Cordeiro. (2003). Educational Leadership: A Problem-based Approach. Boston: Allyn and Bacon.

Dimmock, C., \& A. Walker. (2005). Educational Leadership: Culture and Diversity. Gateshead: Athenaeum Press.

Drucker, Peter F. (1996). Managing the Nonprofit Organization: Principles and Practices. New York: Harpercollins.

Frase, L. E., \& Sorenson, L. (1992). Teacher Motivation and Satisfaction: Impact on Participatory Management. NASSP Bulletin. http://dx.doi.org/10.1177/019263659207654007

Hoy, A. W., \& W. K. Hoy. (2003). Instructional Leadership: A Learning-Centered Guide. Boston: Allyn and Bacon.

Kaewkeeyun, P. (2002). Management Education In a School or District to Use Education As a Base. Bangkok: Phapphim.

Leithwood, K. (2006). A review of the research: Educational leadership. The laboratory for student success at the temple university center for research in human development and education. University of Toronto. Retrieved August 28, 2006, from http://www.temple.edu/lss

MacNeill, N., \& others. (2003). Beyond instructional leadership: Towards pedagogic leadership. Paper submitted for presentation at the 2003 annual conference for the Australian Association for Research in Education: Auckland.

McEwan, E. K. (1998). Seven Steps to Effective Instructional Leadership. California: Corwin Press, inc. National Institute of Educational Testing Service. (2012). The O-Net exams grade 6 and Secondary 3 Academic Year 2011. Retrieved from http://thainews.prd.go.th

Office for National Education Standards and Quality Assessment. (2010). External quality assessment, education, basic education second round. Retrieved from http://www.onesqa.or.th/onesqa/th/ reportyear/show_allGoverment.php?SystemMenuI D=1\&Key=335-3427.rar

Office of Roi-Et Primary Educational Service Area 1. (2010). Report on the annual review.

Office of the Secretary of Educational Council. (2010). Revised National Education Plan (2009-2016). Bangkok: Office of the Education Council.

Razik, Taher, A. (2001). Fundamental Concepts of Education Leadership. New York: Merrill Prentice Hall.

Reeves, Jonathan, Bart. (2010). Academic Optimism and Organizational Climate: An Elementary School Effectiveness Test of Two Measures. Tuscaloosa: Alabama.

Rupan, Pornthep. (2003). A Development of The Performance Appraisal System of The Basic Education Institutes Committee. Doctor of Philosophy in Educational Administration, Department of Educational Administration, Faculty of Education, Chulalongkorn University.

Smith, Robert, Timothy. (1991). Characteristics of Effective School Systems in Georgia. Dissertation Abstracts International.

Songprasert, Petcharin. (2007). The Development of Academic Administrative Model By Teamwork in Basic Educational Schools. Doctor of Philosophy Degree in Educational Administration, Naresuan University.

Templer, Andrew, J. (1995). Canadian Journal of Administrative Sciences. A Model of Human Resource Management Effectiveness, 12(1).

Ubben, Gerald. C., \& Others. (2001). Principles: Leadership for Effective schools (7th ed.). United States.

\section{Copyrights}

Copyright for this article is retained by the author(s), with first publication rights granted to the journal.

This is an open-access article distributed under the terms and conditions of the Creative Commons Attribution license (http://creativecommons.org/licenses/by/3.0/). 